\title{
Mycelial compatibility and aggressiveness of Sclerotinia sclerotiorum isolates from Brazil and the United States
}

\author{
Lucimara Junko Koga( ${ }^{(1)}$, Charles Roger Bowen(2), Claudia Vieira Godoy(3), \\ Maria Cristina Neves de Oliveira(3) and Glen Lee Hartman ${ }^{(1)}$
}

\begin{abstract}
(1)University of Illinois, Department of Crop Sciences, 1101 West Peabody Drive, 61801 Urbana, IL, USA. E-mail: ljk3001@yahoo.com.br, ghartman@illinois.edu (2)United States Department of Agriculture, Agricultural Research Services, 1101 West Peabody Drive, 61801 Urbana, IL, USA. E-mail: crbowen@illinois.edu(3)Embrapa Soja, Rodovia João Carlos Strass, CEP 86001-970 Londrina, PR, Brazil. E-mail: claudia.godoy@embrapa.br, mcristina.oliveira@embrapa.br
\end{abstract}

\begin{abstract}
The objective of this work was to evaluate the genetic diversity among Sclerotinia sclerotiorum isolates from Brazil and the USA, assess their aggressiveness variability, and verify the existence of an isolate-cultivar interaction. Isolate variability was determined by mycelial compatibility grouping (MCG), and isolate aggressiveness by cut-stem inoculations of soybean cultivars. Two experiments for MCGs and two for aggressiveness were conducted with two sets of isolates. The first set included nine isolates from the same soybean field in Brazil and nine from the Midwest region of the USA. The second set included 16 isolates from several regions of Brazil and one from the USA. In the first set, 18 isolates formed 12 different MCGs. In the second set, $81 \%$ of the isolates from Brazil grouped into a single MCG. No common MCGs were observed among isolates from Brazil and the USA. The isolates showed aggressiveness differences in the first set, but not in the second. Although aggressiveness differed in the first set, soybean cultivars and isolates did not interact significantly. Cultivar rank remained the same, regardless of the genetic diversity, aggressiveness difference, and region or country of origin of the isolate. Results from screening of soybean cultivars, performed by the cut-stem method in the USA, can be used as reference for researchers in Brazil.

Index terms: Glycine max, Sclerotinia stem rot, disease resistance, screening of cultivars, white mold.

\section{Compatibilidade micelial e agressividade de isolados de Sclerotinia sclerotiorum do Brasil e dos Estados Unidos}

Resumo - O objetivo deste trabalho foi avaliar a diversidade genética entre isolados de Sclerotinia sclerotiorum do Brasil e dos EUA, determinar sua variabilidade quanto à agressividade e verificar a existência de interação isoladocultivar. A variabilidade dos isolados foi determinada por agrupamento de compatibilidade micelial (ACM), e a agressividade dos isolados, por meio de inoculações, com corte da haste, em cultivares de soja. Dois experimentos de ACM e dois de agressividade foram realizados, com dois conjuntos de isolados. O primeiro conjunto incluiu nove isolados, do mesmo campo de soja no Brasil, e nove da região Meio-Oeste dos EUA. O segundo conjunto incluiu 16 isolados de várias regiões do Brasil e um dos EUA. No primeiro conjunto, 18 isolados formaram 12 ACMs diferentes. No segundo conjunto, $81 \%$ dos isolados do Brasil formaram um único ACM. Nenhum ACM comum foi observado entre os isolados do Brasil e dos EUA. Os isolados apresentaram diferenças quanto à agressividade no primeiro conjunto de isolados, mas não no segundo. Embora a agressividade tenha diferido no primeiro conjunto, as cultivares de soja e os isolados não interagiram significativamente. A classificação das cultivares permaneceu a mesma, independentemente da diversidade genética, da diferença quanto à agressividade e da região ou país de origem do isolado. Resultados da seleção de cultivares de soja, realizada pelo método de inoculação de corte da haste nos EUA, podem ser utilizados como referência para pesquisadores no Brasil.

Termos para indexação: Glycine max, podridão-de-esclerotinia, resistência a doenças, seleção de cultivares, mofo-branco.

\section{Introduction}

The fungus Sclerotinia sclerotiorum (Lib.) de Bary is an important pathogen, which infects more than 400 different plant species worldwide (Boland \& Hall, 1994). In soybean [Glycine max (L.) Merr.] the fungus causes Sclerotinia stem rot (white mold), an important yield-reducing disease (Grau \& Hartman, 1999). Disease outbreaks caused by S. sclerotiorum are highly dependent on favorable environmental conditions, which occur when wet weather and moderate temperatures persist during flowering (Grau \& Hartman, 1999). 
Brazil and the USA are the top two soybean producing countries and, despite their climatic differences, Sclerotinia stem rot is considered an important disease in both of them. In Brazil, the first detection of the disease was reported in the 1970s, in the south-central state of Paraná (Yamashita et al., 1978). With the expansion of soybean to the West-Central, North and Northeast regions in the 1980s and 1990s, the disease was reported in subtropical and tropical soybean producing regions, above $700 \mathrm{~m}$ altitude (Görgen et al., 2010). In the USA, the disease was first reported on soybean in Illinois, in 1946 (Chamberlain, 1951). The disease is mostly reported to cause yield losses in the upper Midwest, and was ranked the second most important disease in the USA in 2009, and the fifth over the period from 2006 to 2009 (Koenning \& Wrather, 2010).

Differences in susceptibility to $S$. sclerotiorum of soybean germplasm have been reported in field and in greenhouse trials (Boland \& Hall, 1987; Hoffman et al., 2002). Screening for resistance under field conditions is often problematic because of the sporadic nature of disease outbreaks. Even with irrigation and inoculation, soybean genotypes vary in canopy architecture, flowering date, and lodging, all of which affect disease development (Boland \& Hall, 1987; Miklas et al., 2003; Bolton et al., 2006). Greenhouse and laboratory evaluations are often performed and are an integral part of resistance screening methodology for $S$. sclerotiorum (Kim et al., 2000; Vuong et al., 2004).

Many inoculation methods have been developed to evaluate resistance to $S$. sclerotiorum, and methods can affect cultivar response. Kull et al. (2003) compared three methods of inoculation to identify levels of resistance to $S$. sclerotiorum in soybean and dry bean, and concluded that the cut-stem method was more precise for detecting main effects and interactions than the cotyledon and detached leaf methods. Unfortunately, field and greenhouse screening results have not been shown to be consistently correlated (Boland \& Hall, 1987; Chun et al., 1987). Among the reasons for the differences between field and greenhouse results is the high level of variability among $S$. sclerotiorum isolates (Kohn et al., 1991; Gomes et al., 2011; Litholdo Júnior et al., 2011). Studies with dandelion, soybean, and sunflower have shown that S. sclerotiorum isolates vary in their aggressiveness (Marciano et al., 1983; Kull et al., 2004; Ekins et al., 2011).
Mycelial compatibility groups (MCGs) and DNA marker systems have been used to characterize the genotypic diversity in populations (Kohli \& Kohn, 1998; Atallah et al., 2004; Gomes et al., 2011; Litholdo Júnior et al., 2011). The method to determine MCGs is broadly adopted for being a macroscopic assay of self/ nonself recognition controlled by multiple loci common in fungi (Kohn et al., 1990). Isolate aggressiveness within geographically and widely dispersed MCGs was shown to vary, but not in MCGs detected within single fields (Kull et al., 2004).

Pathogenic diversity and variation in isolate aggressiveness may influence the success of screening hosts for resistance to S. sclerotiorum, in controlled environments, and for long-term disease management. Therefore, it is important to understand the diversity of this pathogen when developing screening strategies, mainly when results from researchers are shared between widely diverse geographic regions, such as Brazil and the USA.

The objective of this work was to evaluate the genetic diversity among Sclerotinia sclerotiorum isolates from Brazil and the USA, assess their aggressiveness variability, and verify the existence of isolate-cultivar interaction.

\section{Materials and Methods}

Four experiments were conducted with two sets of S. sclerotiorum isolates. From these experiments, two were used for MCG testing and two for aggressiveness evaluation. The first set consisted of nine isolates from Brazil and nine from the Midwest region of the USA. The second set included 16 isolates from widely distributed geographic regions in Brazil and one from the USA. Because of the permit process, these isolates were collected in Brazil and further purified in the USA, at different times, based on when they became available in Brazil for transport.

A total of $24 \mathrm{~S}$. sclerotiorum isolates from Brazil (APHIS permit \#P526-11-02826) and nine from the USA, maintained at the National Soybean Research Center at the University of Illinois, were used in the experiments (Table 1). Brazilian isolates from BR1 to BR9 were collected at random from different infected sunflower plants in a single field, in Mauá da Serra, Paraná state. Isolates from BR10 to BR24 were collected from diverse soybean producing areas, with 
the furthest isolate separation of about $2,000 \mathrm{~km}$. The USA isolates, US1 to US9, were sampled from the upper Midwest.

Isolates BR1 to BR9 and isolates US1 to US9 were used in the first experiment, and isolates BR9 to BR24 and isolate US1, in the second. This single isolate had been used extensively in a previous study of soybean reaction to $S$. sclerotiorum (Chawla et al., 2013). Bulk of sclerotia collected in the field, or reproduced on potato dextrose agar, PDA (Difco Laboratories, Detroit, MI, USA) medium, were air-dried, then collected and stored in capped tubes at $4^{\circ} \mathrm{C}$. From each collection, a single sclerotium was immersed sequentially in $4 \%$ sodium hypochlorite (4 min), $70 \%$ ethanol (2 $\mathrm{min}$ ), rinsed twice in sterile distilled water, and plated in PDA medium. The plates were incubated in a tissue chamber (Percival Scientific, Inc., Boone, IA) set to $12 / 12$ light/dark-hour photoperiods at $23^{\circ} \mathrm{C}$, for 5 days. The isolates were transferred to water-agar medium for three days of incubation at $23^{\circ} \mathrm{C}$; and hyphal tip cultures were produced by cutting tips of hyphae from the outer edge of the colony; these tip cultures were then transferred to another PDA plate.
The purified cultures were maintained on PDA at $4{ }^{\circ} \mathrm{C}$. All inoculations, in each experiment, were made with fresh colonies transferred from the storage cultures onto new PDA plates, for 72 hours, in 12/12 light/ dark-hour photoperiods at $20 \pm 2{ }^{\circ} \mathrm{C}$, prior to each experiment.

For evaluating mycelial compatibility groups, a $6 \mathrm{~mm}$ plug was taken from each isolate, $1 \mathrm{~cm}$ inside the growing edge of the colony, and placed in PDA $(9 \mathrm{~cm}$ Petri plate) amended with $75 \mu \mathrm{L} \mathrm{L}^{-1}$ of McCormick's red food coloring, according to Schafer \& Kohn (2006). The two sets of isolates were paired $3.5 \mathrm{~cm}$ apart in all possible combinations, followed by incubation in 12/12 light/dark-hour photoperiods at $20 \pm 2^{\circ} \mathrm{C}$. Mycelial compatibility and incompatibility reactions were recorded 7 and 10 days after inoculation, based on Kull et al. (2004). Each experiment was repeated.

In order to assess isolate aggressiveness and isolate-cultivar interactions, the same sets of isolates were used in two separate experiments. The cultivars used were DSR 2400, IP 2991, and Resnik. Cultivar Pioneer 93M11 was added to these in the second experiment. These cultivars were selected based on

Table 1. Description of the Sclerotinia sclerotiorum isolates used.

\begin{tabular}{|c|c|c|c|c|}
\hline Isolate & Host & Location/State & Year & Source \\
\hline$\overline{\text { BR1-9 }}$ & Sunflower & Mauá da Serra, Paraná & 2010 & Embrapa \\
\hline BR10 & Soybean & Rio Verde, Goiás & 2010 & Embrapa \\
\hline BR11 & Soybean & Mineiros, Goiás & 2010 & Embrapa \\
\hline BR12 & Soybean & Silvania, Goiás & 2011 & Embrapa \\
\hline BR13 & Soybean & Planaltina, Distrito Federal & 2011 & Embrapa \\
\hline BR14 & Soybean & Unaí, Minas Gerais & 2011 & Embrapa \\
\hline BR15 & Soybean & Chapadão do Sul, Mato Grosso do Sul & 2010 & Embrapa \\
\hline BR16 & Soybean & Estrela do Sul, Minas Gerais & 2012 & Embrapa \\
\hline BR17 & Soybean & Jataí, Goiás & 2012 & Embrapa \\
\hline BR18 & Soybean & Leopoldo de Bulhões, Goiás & 2012 & Embrapa \\
\hline BR19 & Soybean & São Desidério, Bahia & 2012 & Embrapa \\
\hline BR20 & Soybean & Correntina, Bahia & 2012 & Embrapa \\
\hline $\mathrm{BR} 21$ & Soybean & Luís Eduardo Magalhães, Bahia & 2012 & Embrapa \\
\hline BR22 & Soybean & Barreiras, Bahia & 2012 & Embrapa \\
\hline BR23 & Soybean & Palmeira, Paraná & 2012 & Embrapa \\
\hline BR24 & Soybean & Jaciara, Mato Grosso & 2012 & Embrapa \\
\hline US1 & Soybean & Iowa & - & J.Q. Liu \\
\hline US2 & Soybean & Story City, Iowa & 1996 & G. Hartman \\
\hline US3 & Soybean & Fond du Lac County, Wisconsin & 2002 & G. Grau \\
\hline US4 & Soybean & Iowa & 2002 & X.B. Yang \\
\hline US5 & Soybean & Licking County, Ohio & 2002 & A. Dorrance \\
\hline US6 & Soybean & DeKalb, Illinois & 1998 & G. Hartman \\
\hline US7 & Soybean & North Dakota & 2002 & B. Nelson \\
\hline US8 & Soybean & NWM, Ohio & - & A. Dorrance \\
\hline US9 & Soybean & Saint Paul, Minnesota & - & J. Kurle \\
\hline
\end{tabular}


their response to Sclerotinia stem rot in the Varietal Information Program for Soybeans, which reported a greater susceptibility in Pioneer 93M11, followed by Resnik, DSR 2400, and IP 2991 (National Soybean Research Laboratory, 2011). Six seeds of each cultivar were sown in soil-less planting mix Sunshine mix, LC1 (Sun Gro Horticulture Inc., Bellevue, WA, USA) in $15 \mathrm{~cm}$ diameter plastic pots, and fertilized with slow-release pellets (Osmocote 13-13-13). After germination, plants were thinned to four plants per pot. Pots were kept in a greenhouse at $27^{\circ} \mathrm{C}$ average temperature, with $600 \mathrm{Wm}^{-2}$ supplemental illumination, from sowing until inoculation.

Soybean plants at growth stage V3 to V4 (Fehr et al., 1971) were inoculated using the cut-stem method (Kull et al., 2003) by removing the apical stem with a razorblade, $3 \mathrm{~cm}$ above the top fully expanded leaf node. Pipette tips $(200 \mu \mathrm{L})$ were inserted into the outer edge of actively growing $S$. sclerotiorum cultures in Petri-plate PDA. Inocula were removed with the agar plugs inside the base of the pipette tips. The pipette tips with inocula were placed over the cut-stem. After inoculation, plants were transferred to a mist chamber with $100 \%$ humidity, for 24 hours, inside an air-conditioned greenhouse set at $21-23^{\circ} \mathrm{C}$. Plants were kept in the greenhouse for 10 days after inoculation, when stem lesion lengths were measured.

Soybean cultivars and isolates of $S$. sclerotiorum were arranged in a complete block experimental design, with a split plot arrangement, and three replicates. The main plot was formed by the isolates, and the subplot by the cultivars. Experimental units were single pots with four plants as samples. Each of the experiments with each set of isolates was repeated twice.

Data were analyzed for normality and independence of errors, additivity, and homogeneity of variances. Isolate effects on lesion length were tested by $\mathrm{F}$ test in the analysis of variance. Means were compared by Tukey's honestly significant difference, at $5 \%$ probability. Statistical analysis was performed with SAS 9.3. software (SAS Institute, Cary, NC, USA). The test for homogeneity of variances showed that data from repeated experiments could be combined for analysis.

\section{Results and Discussion}

Twelve MCGs were identified in the experiment in the first set, with $18 \mathrm{~S}$. sclerotiorum isolates
(Table 2). Isolates from Brazil formed six MCGs: two represented by groups of two and three isolates, and four by single isolates. USA isolates also formed six MCGs: one represented by four isolates collected from Iowa (two isolates), Wisconsin (one isolate), and North Dakota (one isolate); and five represented by single isolates from Iowa, Illinois, Minnesota, plus two from Ohio State. The isolates from Brazil and USA were not compatible.

Four MCGs were identified in the second set, with $16 \mathrm{~S}$. sclerotiorum isolates from Brazil and one from the USA (Table 2). One MCG was represented by 12 isolates collected from the states of Goiás (five isolates), Distrito Federal (one isolate), Mato Grosso do Sul (one isolate), Minas Gerais (two isolates), and Bahia (three isolates). From the other three MCGs, one consisted of two isolates from Paraná state, one of a single isolate from Bahia state, and one of a single isolate from the USA.

Diversity among isolates collected in the same field, in Mauá da Serra, Paraná, Brazil, was observed on MCGs. Similarly, high diversity was observed among isolates from the Midwestern USA. The first report of S. sclerotiorum infecting soybean in Brazil was from Paraná state in 1976/1977 (Yamashita et al., 1978). This is the same state from where S. sclerotiorum isolates BR1-9 were collected. The first report of $S$. sclerotiorum on soybean in the USA was from Illinois in 1946 (Chamberlain, 1951). Studies on DNA fingerprints and MCGs have shown that S. sclerotiorum populations show a higher diversity on a local scale, where boundaries have been established by genetic or phylogenetic means (Malvárez et al., 2007). Thus, the high diversity in the isolates found in that Brazilian field might indicate that population boundaries were present, favoring some level of outcrossing in addition to the probable intra-clonal variation, since each clone can

Table 2. Number of isolates and mycelial compatibility groups (MCGs) observed in the experiments with two set of isolates of Sclerotinia sclerotiorum: BR1 to BR9, and US1 to US9 (set 1); and BR9 to BR24 and US1 (set 2).

\begin{tabular}{lcc}
\hline \multicolumn{2}{l}{ Isolates MCGs } & MCGs identified \\
\hline 18 & 12 & $\begin{array}{l}\text { BR1; BR2, BR3, and BR5; BR4 and BR8; BR6; BR7; BR9; } \\
\text { US1, US3, US4, and US7; US2; US5; US6; US8; and US9 }\end{array}$ \\
\hline & & Set 2 \\
17 & 4 & BR9 and BR23; BR10-BR21 and BR24; BR22; and US1
\end{tabular}


accumulate mutations and generate new genotypes, as reported elsewhere (Atallah et al., 2004; Kohli \& Kohn, 1998; Malvárez et al., 2007; Wu \& Subbarao, 2006).

In experiment two, $81 \%$ of the isolates from Brazil belonged to a single MCG, even though these isolates were sampled over an extensive area with the furthest isolate separation of about $2,000 \mathrm{~km}$. The low variability in the second set could be explained by the small sample size, or by the recent expansion of soybean crop to the Cerrado region in the last two decades, which includes the states of Minas Gerais and Bahia (Görgen et al., 2010). The presence of common MCGs within a wide geographic distribution in Brazil was reported before (Litholdo Júnior et al., 2011). These isolates may have originated from a common isolate which was disseminated through sclerotia/ mycelia on contaminated uncertified seeds, or on shared farm equipment. A similar pattern was observed in a trans-Canadian study of $S$. sclerotiorum isolated from canola, in which one genotype was sampled in Manitoba and Saskatchewan provinces, while other MCGs or singleton genotypes were less common (Kohli et al., 1992).

There were no isolates from Brazil in the same MCG as USA isolates in neither experiment. Isolates of $S$. sclerotiorum from different countries have been reported to have both same and different MCGs. For example, some $S$. sclerotiorum isolates from the USA belonged to the same MCG as isolates from Canada and Switzerland, while other isolates from the USA were in the same MCG as isolates from Argentina (Kull et al., 2004). Other reports indicated lack of common MCGs in S. sclerotiorum isolates from North Carolina and Canada or North Carolina and Louisiana (Cubeta et al., 1997), and Canada, China, and England (Li et al., 2008). This lack of common MCGs may result of specific selection of MCG genotypes, due to differences in their adaptability to environmental conditions (Atallah et al., 2004; Kull et al., 2004). The ability of certain S. sclerotiorum genotypes to adapt to different environments may explain their presence over large areas. In the present study, isolates collected from the same region, either in Brazil or in the USA (experiment one), showed a high diversity and were incompatible between countries. The isolates sampled from a wide Brazilian domain (experiment two) were highly homogeneous, but the isolates from the southern subtropical region, BR9 and BR23 (same MCG), were incompatible with isolates from the tropical region, suggesting differences in the origin of introduction, or reinforcing the role played by the environmental differences.

As to isolate aggressiveness, lesion lengths differed significantly among isolates in the experiment using set one isolates (Figure 1). Lesion lengths ranged from

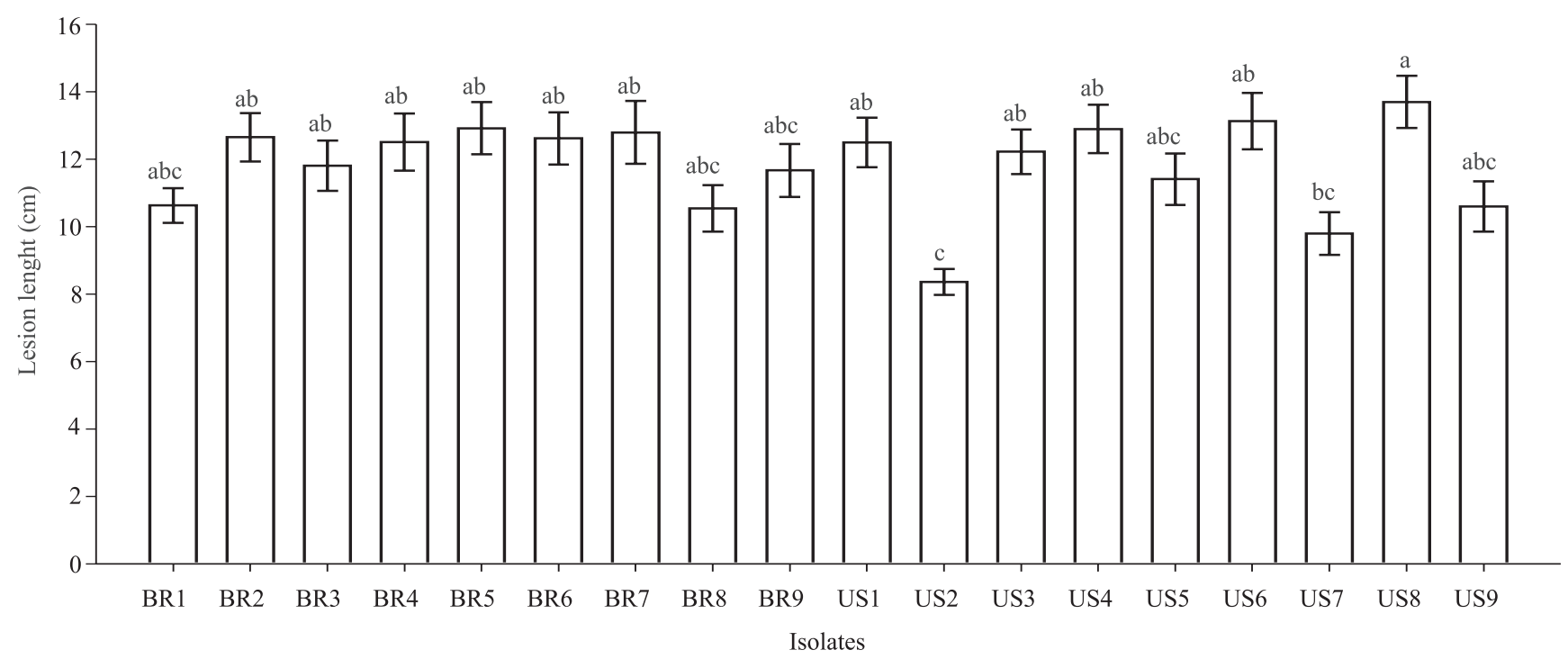

Figure 1. Average lesion length (cm) and standard errors of soybean cultivars (Resnik, DRS 2400 and IP 2991) inoculated with Sclerotinia sclerotiorum isolates BR1-BR9, collected from the same field in Mauá da Serra, Paraná, Brazil; and US1-US9, collected from the USA Midwestern locations. Bars followed by equal letters do not differ by Tukey's honestly significant difference test at $1 \%$ probability. 
8.3 to $13.7 \mathrm{~cm}($ mean $=11.8)$. Isolate US2 $($ collected in Iowa) produced the lowest lesion length, but did not differ from isolates BR1, BR8, and BR9 collected in the same location in Brazil (Mauá da Serra, Paraná), or from US5 (Ohio), US7 (North Dakota), and US9 (Minnesota).

No significant difference in lesion length was observed for the isolates in the experiment two, which ranged from 5.9 to $6.7($ mean $=6.3)$. The average lesion length in response to inoculation with $S$. sclerotiorum isolates from Brazil was similar to that with the US1 isolate from Iowa.

Cultivars differed significantly in sets one and two (Tables 3 and 4). Resnik had the longest lesion length in both experiments, while DSR 2400, IP 2991, and 93M11 did not significantly differ in neither of experiments (Table 4).

The analyses of variance for lesion length did not indicate interaction between isolates and cultivars (Table 3). However, isolate by cultivar interaction was previously reported for plants inoculated by cut-stem method, but plants were at an earlier stage

Table 3. Analysis of variance combined over two runs of experiments, with two sets of Sclerotinia sclerotiorum isolates.

\begin{tabular}{lccccccc}
\hline Source of & \multicolumn{4}{c}{ Experiment 1} & & \multicolumn{3}{c}{ Experiment 2 } \\
\cline { 2 - 4 } \cline { 6 - 8 } variation & df & Mean square & F ratio & & df & Mean square & F ratio \\
\hline Isolate & 17 & 33.45 & $6.08^{* * * *}$ & & 16 & 1.39 & $1.04^{\mathrm{ns}}$ \\
Error (A) & 34 & 5.50 & - & & 32 & 1.34 & - \\
Cultivar & 2 & 259.17 & $27.07^{* * *}$ & 3 & 155.98 & $137.43^{* * *}$ \\
Isolate $\mathrm{x}$ & 34 & 5.29 & $0.55^{\mathrm{ns}}$ & & 48 & 1.20 & $1.06^{\mathrm{ns}}$ \\
cultivar & & & & & & & \\
Error (B) & 180 & 9.57 & - & 238 & 1.13 & - \\
\hline
\end{tabular}

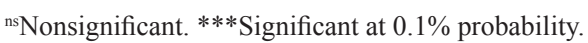

Table 4. Sclerotinia sclerotiorum lesion length $(\mathrm{cm})$ on soybean cultivars ${ }^{(1)}$.

\begin{tabular}{lcc}
\hline Cultivars & Experiment 1 & Experiment 2 \\
\hline Resnik & $13.5 \mathrm{a}$ & $8.2 \mathrm{a}$ \\
DRS 2400 & $11.5 \mathrm{~b}$ & $5.5 \mathrm{~b}$ \\
IP 2991 & $10.4 \mathrm{~b}$ & $5.7 \mathrm{~b}$ \\
93M11 & - & $5.9 \mathrm{~b}$ \\
\hline
\end{tabular}

${ }^{(1)}$ Means followed by equal letters do not differ by Tukey's honestly significant difference test at $1 \%$ probability.
(V2) than in this study, and infection was quantified by the number of dead plants (Kull et al., 2004). In the present study, the presence or absence of differences in aggressiveness among isolates did not change soybean cultivar resistance rank.

Understanding the genetic diversity and differences in aggressiveness of $S$. sclerotiorum isolates across geographic regions is important to forecast disease epidemiology, population dynamics, and to define lasting breeding strategies for resistance. Both aggressiveness differences (experiment one) and lack of difference (experiment two) were reported in former publications. Differences in isolate aggressiveness have been reported for soybean (Kull et al., 2004), canola (Kohli et al., 1995), and sunflower (Ekins et al., 2011; Marciano et al., 1983), while lack of significant differences in aggressiveness was reported among isolates collected from Canada and inoculated in soybean (Auclair et al., 2004), or collected in the USA and inoculated in potato (Atallah et al., 2004). The overall lesion lengths measured in the experiment two of this study were shorter than in experiment one, possibly due to growing conditions in the greenhouse related to planting dates throughout two years. Since resistance to S. sclerotiorum in crops has been reported to be quantitative or incomplete, phenotyping may be affected by different environmental conditions.

This study supports the use of USA screening results in Brazil, since isolate's genetic diversity and aggressiveness, and separation of susceptible and more resistant soybean cultivars were independent from country or isolate's region of origin.

Routine screenings for Sclerotinia stem rot have been performed in the USA. However, they have not been adopted yet in the majority of Brazilian breeding programs because of the recent and sporadic disease outbreaks. Although research results to date did not find reliable physiological resistance, screening and selecting less susceptible genotypes for breeding with commercial cultivars could help manage the disease.

\section{Conclusion}

The results from cut-stem method screenings carried out in the USA for Sclerotinia sclerotiorum resistance can be used as reference for researchers in Brazil. 


\section{Acknowledgements}

To Conselho Nacional de Desenvolvimento Científico e Tecnológico (CNPq), for fellowship granted; to Dr. Maurício Meyer, for providing S. sclerotiorum isolates from Brazilian Cerrado region.

\section{References}

ATALlAH, Z.; LARGET, B.; CHEN, X.; JOHNSON, D. High genetic diversity, phenotypic uniformity, and evidence of outcrossing in Sclerotinia sclerotiorum in the Columbia Basin of Washington State. Phytopathology, v.94, p.737-742, 2004. DOI: 10.1094/PHYTO.2004.94.7.737.

AUCLAIR, J.; BOLAND, G.J.; COBER, E.; GRAEF, G.L.; STEADMAN, J.R.; ZILKA, J.; RAJCAN, I. Development of a new field inoculation technique to assess partial resistance in soybean to Sclerotinia sclerotiorum. Canadian Journal of Plant Science, v.84, p.57-64, 2004. DOI: 10.4141/P03-035.

BOLAND, G.; HALL, R. Evaluating soybean cultivars for resistance to Sclerotinia sclerotiorum under field conditions. Plant Disease, v.71, p.934-936, 1987. DOI: 10.1094/PD-71-0934.

BOLAND, G.; HALL, R. Index of plant hosts of Sclerotinia sclerotiorum. Canadian Journal of Plant Science, v.16, p.93-108, 1994.

BOLTON, M.D.; THOMMA, B.P.; NELSON, B.D. Sclerotinia sclerotiorum (Lib.) de Bary: biology and molecular traits of a cosmopolitan pathogen. Molecular Plant Pathology, v.7, p.1-16, 2006. DOI: 10.1111/j.1364-3703.2005.00316.x.

CHAMBERLAIN, D. Sclerotinia stem rot of soybeans. Plant Disease Report, v.35, p.490-491, 1951.

CHAWLA, S.; BOWEN, C.R.; SLAMINKO, T.L.; HOBBS, H.A.; HARTMAN, G.L. A public program to evaluate commercial soybean cultivars for pathogen and pest resistance. Plant Disease, v.97, p.568-578, 2013. DOI: 10.1094/PDIS-05-12-0479-FE.

CHUN, D.; KAO, L.; LOCKWOOD, J.; ISLEIB, T. Laboratory and field assessment of resistance in soybean to stem rot caused by Sclerotinia sclerotiorum. Plant Disease, v.71, p.811-814, 1987. DOI: 10.1094/PD-71-0811.

CUBETA, M.; CODY, B.; KOHLI, Y.; KOHN, L. Clonality in Sclerotinia sclerotiorum on infected cabbage in eastern North Carolina. Phytopathology, v.87, p.1000-1004, 1997. DOI: 10.1094/PHYTO.1997.87.10.1000.

EKINS, M.; HAYDEN, H.; AITKEN, E.; GOULTER, K. Population structure of Sclerotinia sclerotiorum on sunflower in Australia. Australasian Plant Pathology, v.40, p.99-108, 2011. DOI: $10.1007 / \mathrm{s} 13313-010-0018-6$.

FEHR, W.; CAVINESS, C.; BURMOOD, D.; PENNINGTON, J. Stage of development descriptions for soybeans, Glycine max (L.) Merrill. Crop Science, v.11, p.929-931, 1971. DOI: 10.2135/crops ci1971.0011183X001100060051x.

GOMES, E.V.; NASCIMENTO, L.B. do; FREITAS, M.A. de; NASSER, L.C.B.; PETROFEZA, S. Microsatellite markers reveal genetic variation within Sclerotinia sclerotiorum populations in irrigated dry bean crops in Brazil. Journal of Phytopathology, v.159, p.94-99, 2011. DOI: 10.1111/j.1439-0434.2010.01724.x.

GÖRGEN, C.; HIKISHIMA, M.; SILVEIRA NETO, A.; CARNEIRO, L.; LOBO JUNIOR, M. Mofo-branco (Sclerotinia sclerotiorum). In: ALMEIDA, A.; SEIXAS, C. (Ed.). Soja: doenças radiculares e de hastes e inter-relações com o manejo do solo e da cultura. Londrina: Embrapa Soja, 2010. p.73-104.

GRAU, C.; HARTMAN, G. Sclerotinia stem rot. $4^{\text {th }}$ ed. St. Paul: APS Press, 1999. p.46-48. (Compendium of soybean diseases).

HOFFMAN, D.D.; DIERS, B.W.; HARTMAN, G.L.; NICKELL, C.D.; NELSON, R.L.; PEDERSEN, W.L.; COBER, E.R.; STEADMAN, J.R.; GRAU, C.R.; NELSON, B.D.; DEL RIO, L.E.; HELMS, T.; ANDERSON, T.; POYSA, V.; RAJCAN, I.; STIENSTRA, W.C.; GRAEF, G.L. Selected soybean plant introductions with partial resistance to Sclerotinia sclerotiorum. Plant Disease, v.86, p.971-980, 2002. DOI: 10.1094/ PDIS.2002.86.9.971.

KIM, H.; HARTMAN, G.; MANANDHAR, J.; GRAEF, G.; STEADMAN, J.; DIERS, B. Reaction of soybean cultivars to Sclerotinia stem rot in field, greenhouse, and laboratory evaluations. Crop Science, v.40, p.665-669, 2000. DOI: 10.2135/ cropsci2000.403665x.

KOENNING, S.R.; WRATHER, J.A. Suppression of soybean yield potential in the continental United States by plant diseases from 2006 to 2009. Plant Health Program, online, 2010. DOI: 10.1094/PHP-2010-1122-01-RS.

KOHLI, Y.; BRUNNER, L.; YOELL, H.; MILGROOM, M.; ANDERSON, J.; MORRALL, R.; KOHN, L. Clonal dispersal and spatial mixing in populations of the plant pathogenic fungus, Sclerotinia sclerotiorum. Molecular Ecology, v.4, p.69-77, 1995. DOI: 10.1111/j.1365-294X.1995.tb00193.x.

KOHLI, Y.; KOHN, L.M. Random association among alleles in clonal populations of Sclerotinia sclerotiorum. Fungal Genetics and Biology, v.23, p.139-149, 1998. DOI: 10.1006/fgbi.1997.1026.

KOHLI, Y.; MORRALL, R.; ANDERSON, J.; KOHN, L. Local and trans-Canadian clonal distribution of Sclerotinia sclerotiorum on canola. Phytopathology, v.82, p.875-880, 1992. DOI: 10.1094/ Phyto-82-875.

KOHN, L.; STASOVSKI, E.; CARBONE, I.; ROYER, J.; ANDERSON, J. Mycelial incompatibility and molecular markers identify genetic variability in field populations of Sclerotinia sclerotiorum. Phytopathology, v.81, p.480-485, 1991. DOI: 10.1094/Phyto-81-480.

KOHN, L.M.; CARBONE, I.; ANDERSON, J.B. Mycelial interactions in Sclerotinia sclerotiorum. Experimental Mycology, v.14, p.255-267, 1990. DOI: 10.1016/0147-5975(90)90023-M.

KULL, L.; PEDERSEN, W.; PALMQUIST, D.; HARTMAN, G. Mycelial compatibility grouping and aggressiveness of Sclerotinia sclerotiorum. Plant Disease, v.88, p.325-332, 2004. DOI: 10.1094/ PDIS.2004.88.4.325.

KULL, L.S.; VUONG, T.D.; POWERS, K.S.; ESKRIDGE, K.M.; STEADMAN, J.R.; HARTMAN, G.L. Evaluation of resistance screening methods for Sclerotinia stem rot of soybean and dry 
bean. Plant Disease, v.87, p.1471-1476, 2003. DOI: 10.1094/ PDIS.2003.87.12.1471.

LI, Z.; ZHANG, M.; WANG, Y.; LI, R.; FERNANDO, W. Mycelial compatibility group and pathogenicity variation of Sclerotinia sclerotiorum population in sunflower from China, Canada and England. Plant Pathology Journal, v.7, p.131-139, 2008. DOI: 10.3923/ppj.2008.131.139.

LITHOLDO JÚNIOR, C.G.; GOMES, E.V.; LOBO JÚNIOR, M.; NASSER, L.C.; PETROFEZA, S. Genetic diversity and mycelial compatibility groups of the plant-pathogenic fungus Sclerotinia sclerotiorum in Brazil. Genetics and Molecular Research, v.10, p.868-877, 2011. DOI: 10.4238/vol10-2gmr937.

MALVÁREZ， G.; CARBONE， I.; GRÜNWALD， N.J.; SUBBARAO, K.V.; SCHAFER, M.; KOHN, L.M. New populations of Sclerotinia sclerotiorum from lettuce in California and peas and lentils in Washington. Phytopathology, v.97, p.470-483, 2007. DOI: 10.1094/PHYTO-97-4-0470.

MARCIANO, P.; DI LENNA, P.; MAGRO, P. Oxalic acid, cell wall-degrading enzymes and $\mathrm{pH}$ in pathogenesis and their significance in the virulence of two Sclerotinia sclerotiorum isolates on sunflower. Physiological Plant Pathology, v.22, p.339-345, 1983. DOI: 10.1016/S0048-4059(83)81021-2.

MIKLAS, P.N.; DELORME, R.; RILEY, R. Identification of QTL conditioning resistance to white mold in snap bean. Journal of the
American Society for Horticultural Science, v.128, p.564-570, 2003.

NATIONAL SOYBEAN RESEARCH LABORATORY. Varietal information program for soybeans. Available at: $<$ http://www. vipsoybeans.org/v4/vpCompare/cvCS1.cfm? $\mathrm{b}=\mathrm{y}>$. Accessed on: 11 mar. 2011.

SCHAFER, M.R.; KOHN, L.M. An optimized method for mycelial compatibility testing in Sclerotinia sclerotiorum. Mycologia, v.98, p.593-597, 2006. DOI: 10.3852/mycologia.98.4.593.

VUONG, T.D.; HOFFMAN, D.D.; DIERS, B.W.; MILLER, J.F.; STEADMAN, J.R.; HARTMAN, G.L. Evaluation of soybean, dry bean, and sunflower for resistance to Sclerotinia sclerotiorum. Crop Science, v.44, p.777-783, 2004. DOI: 10.2135/cropsci2004.0777.

WU, B.; SUBBARAO, K.V. Analyses of lettuce drop incidence and population structure of Sclerotinia sclerotiorum and $S$. minor. Phytopathology, v.96, p.1322-1329, 2006. DOI: 10.1094/ PHYTO-96-1322.

YAMASHITA, J.; NASSER, L.; ALMEIDA, A.M.R.; MACHADO, C.C.; FERREIRA, L.P. Ocorrência da fase perfeita do fungo Whetzelinia sclerotiorum (Lib.) Korf \& Dumont, em lavouras de soja no Estado do Paraná. Fitopatologia Brasileira, v.3, p.109, 1978.

Received on February 13, 2014 and accepted on March 31, 2014 